\title{
Legal mechanisms for the protection of the rights of national minorities in local self-government in the Republic of Serbia
}

\section{Pravni mehanizmi za zaštitu prava nacionalnih manjina u lokalnoj samoupravi u Republici Srbiji}

Jovana Anđelkovića ${ }^{\text {a* }}$ Milica Krulj-Mladenovića

a Academy of Professional Studies South Serbia, Business School Blace, Serbia

\begin{abstract}
At the level of local self-governments, the needs and problems of national minorities in the effort to exercise their rights and to integrate can be best identified. Local public policies should strive to improve the existing normative framework, cooperate with the nongovernmental sector and, including the media, constantly work to raise awareness and build an atmosphere that will encourage national minorities to seize opportunities, internationally and nationally recognized, in view of preserving their national identity. Local environments should be characterized by a culture of tolerance, dialogue, seemingly small but essentially large everyday struggles, to build a society that fights against discrimination, respects differences and accepts them. The fight against ingrained prejudices must be constant. The aim of this text is to point out the rights of persons belonging to national minorities, which they can exercise at the local level, the difficulties they face, but also the weaknesses of certain legal solutions. The work also highlights examples of good practice in the protection and respect of the rights of national minorities, which should be followed, especially in AP Vojvodina, which has the largest number of multiethnic municipalities.
\end{abstract}

Keywords: local public policies, tolerance, dialogue, Autonomous Province of Vojvodina

Sažetak: Na nivou lokalnih samouprava najbolje se mogu prepoznati potrebe i problem nacionalnih manjina u nastojanju da ostvare svoja prava i da se integrišu. Lokalne javne politike treba da nastoje da unaprede postojeći normativni okvir, da sarađuju sa nevladinim sektorom i da uključujući medije, konstantno rade na podizanju svesti i izgradnji atmosphere koja će podsticati nacionalne manjine u želji da iskoriste mogućnosti, međunarnodno $i$ nacionalno priznate, a u nameri da sačuvaju svoj nacionalni identitet. Lokalne sredine treba da odlikuje kultura tolerancije, dijaloga, naizgled malih, ali suštinski velikih, svakodnevnih borbi za izgradnju društva koje se bori protiv diskriminacije, uvažava različitosti i prihvata ih.

*Corresponding author

E-mail address: joka2912@gmail.com

This is an open access paper distributed under the license cc) (1) () 
Borba sa ukorenjenim predrasudama, mora da bude konstantna. Cilj rada je da ukaže na prava pripadnika nacionalnih manjina, koja mogu ostvariti na lokalnom nivou, na poteškoće sa kojima se suočavaju, ali i na slabosti pojedinih zakonskih rešenja. U radu se ističu i primeri dobre prakse zaštite i poštovanja prava nacionalnih manjina, koje treba slediti, naročito u AP Vojvodini, koja i ima najveći broj multietničkih opština

Ključne reči: lokalne javne politike, tolerancija, dijalog, Autonomna pokrajina Vojvodina.

\section{Introduction}

The problem of protecting the rights of minorities has been present in the international community for a long time and it could be said that it represents one of the extremely important tests of democracy in the country.

The beginning of the protection of minorities is related to religious rights, so that between the two world wars, this issue was dealt with by the League of Nations, and after the Second World War, it began to be dealt with by the United Nations. "Constitutions and laws in some states gradually guarantee the basic rights of citizens, while in international relations, independent nation-states have been created, so that religion, which previously played a predominant role in international life, has given way to the principle of nationality, as in the West Europe, as well as on the Balkan Peninsula"(Pržić, 1933, p. 13).

One of the ideals of the creation and constant progress of international law is the protection of human rights, especially the protection of those rights, whose path is much more difficult to achieve. The lack of consensus to determine some basic characteristics at the international level, which would contribute to guaranteeing the status of a minority and the realization of minority rights, shows the desire of states to preserve their internal competence in determining such criteria. The question is, in the absence of these elements, is there any room for some kind of latent assimilation of the minorities?

Attempts can also be found in the doctrine ${ }^{1}$ where the notion defines a national minority by the criterion of the number of a minority in relation to the majority population of a state, but this definition is unacceptable because it would imply that the minorities must fight for their rights to enjoy the rights guaranteed by the international and national order, and only in the case of a sufficient number, the threshold which, in that case, would have to be determined by the state.

This would then indicate that those minorities, which do not meet the predicted criterion, are subject to a kind of systemic assimilation, which is inconceivable at the current stage of development of civilization.

\footnotetext{
${ }^{1}$ The definition given by Francesco Capotorti often stands out. In his opinion, the minority includes ,a group numerically smaller than the rest of the population of the state, and whose members, citizens of that state, have ethnic, religious or linguistic characteristics different from the rest of the population and show, albeit implicitly, a sense of solidarity which is aimed at preserving its culture, tradition, religion or language“.
} 
Pravni mehanizmi za zaštitu prava nacionalnih manjina u lokalnoj samoupravi u Republici Srbiji

Thus, the policy and legislation of immigration states on the American continent were inspired by assimilation, which was aimed at the rapid integration of all citizens and the creation of non-ethnic nations. Immigration states hesitated to recognize minorities and their special rights, arguing that the equality of all their citizens is a sufficient democratic guarantee, and that assimilation is a completely natural process. On the other hand, the Federal Government of Germany considers national minorities to be the groups of the population that meet the next five criteria: "1) to be a German citizen; 2) to differ from the majority population in a way that they have their own language, culture and history and thus their own special identity; 3) they want to keep their identity; 4) they traditionally live in Germany (usually for centuries), 5) they live in Germany within traditional settlements" (Nowak, 2005, p. 638).

It is especially important that the issue of protection of minorities should by no means be a reflection of the current state of relations between states, or bad relations in the past. This case is characteristic of the political atmosphere and diplomatic relations of the countries on the Balkan Peninsula. The fact that there is still no readiness of individual states, i.e. their political actors and their policies, to overcome bad relations from the past and to start on the new path of reconciliation and building stable business relations, which would contribute to a better life of the inhabitants of those states, must not question or overshadow the protection of minority rights. The enjoyment of minority rights must not be related to the principle of reciprocity in relations between states, i.e. to the level of acknowledgement, possibility of exercising and protecting the rights of one's own people, in states where it represents a minority. It is also important that the rights enjoyed by minorities are not perceived as a reward for loyalty and respect of the state's constitutional order and its laws. Because if any member of a minority violates the constitutional order of a state or acts contrary to its laws, he, like every citizen, as well as a member of the majority people, will be sanctioned, in accordance with the valid procedure (Pržić, 1933, p. 193) This must not be a way to deny him the rights he enjoys, in an effort to protect his national identity.

The realization of national minority rights will largely depend on the political atmosphere, cultural and social circumstances that exist in a country, and in times of rapid migration processes, the issue of protection of minority rights must be constantly relevant, internationally, at the central level of the state as well as at the level of the local government. The essence of minority rights is in the protection and nurturing the determinants of national identities - language, culture, religion, customs, etc. Individual rights are exercised individually, and collective in community with others, in accordance with the Constitution, law and international treaties (Marković, 2009, p. 67).

The transition in the former socialist countries, including Serbia, to market capitalism began in 1989, at the ideological and political level, followed by nationalism, which became one of the components in creating a new system of government, new values and relations between people. In terms of the composition and number of national minorities, the Republic of Serbia is a very heterogeneous state, which indicates the fact that the policy of protecting the minority rights has a very important role when it comes to good interethnic relations, but also for democratic development and 
prosperity of Serbia which is also the case with states in the region. The protection of minorities must be comprehensive, and in the countries that emerged from the disintegration of the SFRY, special attention must be paid to the so-called ,new minorities", which are representatives of the people of the former Yugoslavia and whose status has changed significantly with the collapse of the great state. Respecting their status and rights greatly contributes to better relations between countries, and thus to regional stability (United Nations Human Rights, 2012). In addition to constitutional proclamation and affirmation of values at the national and international levels, human rights require an effective system of protection, which is generally ensured by guaranteeing the basic principles of the rule of law. "That is why the human rights system is at the same time a condition, but also an outcome of the rule of law" (Pejić, 2009, pp. 55-68).

Whereas the central government adopts the Constitution, laws, ratifies international agreements, the needs and problems of those who are in the minority to exercise their rights and integrate are much clearly seen at the level of local self-governments. Local public policies should strive to improve the existing normative framework, cooperate with the non-governmental sector and, including the media, constantly work to raise awareness and build an atmosphere that will encourage national minorities to seize opportunities, internationally and nationally recognized in order to preserve their national identity. The fight against ingrained prejudices must be constant.

Good minority policy cannot be achieved by applying legislation alone. Some authors believe that this creates a high dose of mistrust, which accumulates and is suppressed in times of crisis, and that when social crises of previously accumulated bad feelings and conditions break out, they end up with violence and crime. "What is said about minorities in privacy, should also be expressed publicly, because in that way a sincere relationship is created and trust is built between different people" (Čupić \& Joković, 2013).

The Committee of Ministers of the Council of Europe adopted in 1994 the Framework Convention for the Protection of National Minorities, which is the first, comprehensive regional international agreement, which is fully dedicated to national minorities (Council of Europe, 1995).

The Law on Local Self-Government (Zakon o lokalnoj samoupravi, 2018) stipulates that one of the competencies of the municipality is to take care of the realization, protection and promotion of human and minority rights. The situation in the Republic of Serbia is such that members of minorities live in most municipalities, but since their number differs, not all municipalities are multiethnic. There is a total of 68 such municipalities in Serbia, of which the largest number is in the Autonomous Province of Vojvodina.

\section{The right to use language and script}

One of the basic rights, which is a prerequisite for exercising many other rights of people belonging to national minorities, is the right to use their own language and script. In terms of the Law on Official Use of Languages and Scripts (Zakon o 
Pravni mehanizmi za zaštitu prava nacionalnih manjina u lokalnoj samoupravi u Republici Srbiji

službenoj upotrebi jezika i pisma, 2005), official use is the use of languages and scripts in: the state bodies, bodies of autonomous provinces, cities and municipalities, institutions, companies and other organizations, when exercising public authority. The use of languages and scripts in the work of public companies and public services, as well as in the work of other organizations when performing tasks determined by this Law, is also considered official use. The mentioned Law stipulates that in the territory of local self-government, where members of national minorities traditionally live, their language and script may be in equal official use, but local self-government units are obliged to introduce the language and script of national minorities into equal official use by their statute if the percentage of members of that national minority in its total reaches $15 \%$ of inhabitants on that territory, according to the results of the last census. In the territories of local self-government units, where the language of a national minority has been introduced into equal official use, the names of bodies exercising public authority, names of local self-government units, settlements, squares and streets and other toponyms should also be written in the language of the respective national minority tradition and spelling. The Assembly of the unit of local selfgovernment should determine by its statute which settlements meet that criterion, having in mind the traditional population of members of the national minority, with the previously obtained opinion of the national council of the national minority.

In theory, there are opinions such as: „The introduction of one minority language into official use has far-reaching consequences, because it obliges all state bodies based in the municipality where the language and script of the national minority are in official use, which burdens local governments and courts too much to solve complex problems of official multilingualism on their own and to be able to adopt all actions and acts in all official languages of the municipality, and that the percentage of $15 \%$ was set irrationally and is economically unjustifiable, and that the purpose of protecting the identity of national minorities and their languages could and be realized differently" (Bašić \& Đorđević, 2010). Examples are Carinthia and Burgenland (Austria), where the percentage is $20-25 \%$ of the population. In Switzerland, the Constitutional Court has ruled that the language of the „majority of the population“ must be taken into account, and that the „majority of the population“ exists when the share of the group in a municipality approaches $50 \%$.

Members of national minorities whose number in the overall population of the Republic of Serbia reaches at least $2 \%$ according to the last census may address the republican authorities in their own language and have the right to receive an answer in that language, but also members of national minorities whose number in the overall population of the Republic of Serbia does not reach $2 \%$ according to the last census can address the republican authorities in their own language and have the right to receive an answer in that language through the local self-government unit in which the language of that national minority is in official use, with the local self-government unit providing translation and bearing translation costs addressed to the republic body and the response of that body. The defect of the legal solution is noticeable here, on the example of the Roma national minority (Dimitrijević \& Vučetić, 2015, pp. 229251). Namely, in a large number of local governments, according to official censuses, the Roma population reaches the legal threshold of $2 \%$ of the population, but does not 
exercise the mentioned rights. In support of this, claims have been made for years about the insufficient standardization of the Romani language and the absence of a literary Romani language. The decision on the standardization of the Romani language in the Republic of Serbia was made by the National Council of the Romani National Minority in Serbia (September 30, 2013). In addition to various actions of support and assistance provided by the state and local self-government to members of the Roma national minority, without enabling the use of their own language and script, official use of language and script and education in their mother tongue, there can be no substantial progress. The extremely bad situation regarding the Roma national minority was also pointed out in the last report (published on December 18, 2019) of the Council of Europe on the implementation of the Framework Convention (Council of Europe, 2019).

The Hungarian language and script are in official use in the units of local selfgovernment in the Autonomous Province of Vojvodina, in the work of bodies and organizations of AP Vojvodina. The Slovak language and script are in official use in 13 cities and municipalities, Romanian in ten, Ruthenian in six, and Croatian in four. According to the Statute of AP Vojvodina from 2009, all the mentioned languages are in official use in the work of provincial bodies and organizations. On the territory of AP Vojvodina, there is also the Czech language and alphabet, which are in official use in the municipality of BelaCrkva, and the Macedonian language and alphabet in official use in the settlement of Jabuka, which is part of the city of Pancevo and in the local community of Duzine in the municipality of Plandiste. Albanian is in official use in the municipalities of Bujanovac, Medvedja and Presevo, Bosnian in the cities of Novi Pazar and the municipalities of Prijepolje, Sjenica and Tutin, and Bulgarian in the municipalities of Bosilegrad and Dimitrovgrad. The Bulgarian language is in official use in the settlement of Ivanovo, which is on the territory of the city of Pancevo. In its latest report, the Council of Europe praised the situation and level of protection of minority rights in Vojvodina, in relation to the rest of Serbia, but the report pointed out that this issue still needs to be worked on, especially the issue of the rights of the Roma national minority (Bašić \& Đorđević, 2010).

The Protector of Citizens, in cooperation with his research team, prepared a special report on the official use of the Albanian language and script, which states that the situation on this issue has improved significantly compared to the previous period. In the municipality of Bujanovac, Presevo's improvement is first reflected in the fact that bilingualism is ensured during the drafting of official acts, and this is especially evident in public inscriptions. It is important to point out that, despite the limitations of the local budget, the boards with street inscriptions were made bilingually and after that they replaced the previous ones. Having in mind the fact that significant funds are needed for the official use of languages and scripts at the local level, the Protector of Citizens was pointed out by the municipal administration that funds from the state budget would significantly contribute to the consistent and efficient implementation of the law. In a situation when local governments do not have the funds to replace all the boards, without the financial help of the Republic of Serbia, the replacement of the boards will take couple of years. The Protector of Citizens noticed that the mentioned local self-governments still did not provide bilingual boards of branches / subbranches of the republic state bodies, in Serbian and Albanian language and script, 
Pravni mehanizmi za zaštitu prava nacionalnih manjina u lokalnoj samoupravi u Republici Srbiji

which was pointed out to them. Due to frequent erroneous entries of Albanian names and surnames in the registry book, which makes it difficult for parties to exercise many other rights, primarily the right to personal documents, the Ministry of State Administration and Local Self-Government began drafting the Catalog of Albanian Names, which will help solve this problem (Zaštitnik građana, 2018).

\section{The right to work education and public information}

One of the most important rights, which is often a question of survival in the territories of local self-government units, both members of the majority and minority people, is the right to work. In that sense, special attention should be paid to creating conditions for employment of members of national minorities in local self-governments and public institutions, to create such a environment that will prevent the emergence of any form of discriminatory employment practices (Belton et al, 1999). Thus, in the provincial bodies and services established by AP Vojvodina, the employment takes into account the national composition of the population and the appropriate representation of members of national minorities - national communities in accordance with the Constitution and the law, and in the case of significant disparity in the representation of members of national minorities in provincial bodies and services established by AP Vojvodina, the Provincial Government is obliged to take special measures and activities, such as a special scholarship and training program for trainees and other measures and activities. Such measures and activities last as long as there are significant disproportionate representation, provided that they cannot jeopardize the work in the provincial bodies and services established by AP Vojvodina, nor the general conditions of employment in them.

The right to acquire knowledge through education, in accordance with the binding system of the Republic of Serbia, is an important segment of the integration of national minorities into the local community and society as a whole (Nikčević et al, 2021). Preservation of the cultural identity and singularity of minorities also contributes to the diversity of a country's cultural wealth. The Constitution of the Republic of Serbia guarantees members of national minorities the right to education in their own language in state institutions and institutions of the autonomous provinces, as well as to establish private educational institutions, in order to preserve their uniqueness. It is the right of national minorities, directly or through their representatives, to participate in decision-making or to decide for themselves on certain issues related to their culture and education (Ustav RS, 2006).

Thus, the Union of Hungarian Students sued the Faculty of Law of the University of Novi Sad, stating that this Faculty behaves discriminatory towards members of the Hungarian national minority, because when taking the entrance exam for enrollment, it requires candidates to take Serbian language and literature. The Association of Hungarian Students first sued the Faculty of Law in 2015 for discrimination, i.e. preventing students from taking entrance exams in their mother tongue. The court ruled that the faculty has an obligation to organize admissions in minority languages. The faculty fulfilled the obligation to take the entrance exam in the mother tongue, but it also organized a Serbian language test for students who took the exam in Hungarian, 
which was a new reason for the lawsuit, and which adjudicated that the faculty acted discriminatory in this case as well (Minority news, 2019).

The right to public information is one of the rights that, with the privatization of the media and the transition to their project financing, is seriously endangered in Serbia and it is necessary, especially for local governments, to recognize and make additional efforts, in order to make sure that this extremely important right would not become thwarted and put in the background, because it is a prerequisite for the realization of many rights of persons belonging to national minorities. As the adoption of the budget in local self-governments depends on the majority of councilors, it can happen that the lack of will, current political factors of local self-government by voting for a smaller budget for co-financing the media in the language of national minorities, jeopardizing the meaning of this right. The Constitution of the Republic of Serbia guarantees the freedom of the media, Art. 79 establishes the right of national minorities to a complete, timely and impartially inform themselves in their own language, including the right to „express, receive, send and exchange information and ideas“, as well as to establish their own media, in accordance with the law.It is also extremely important for those cities to promote, highlight and publicly present good practices, respect and contribute to the protection and promotion of the rights of national minorities, municipalities and urban municipalities in Serbia. It is noticeable, however, that good examples of treatment when it comes to members of national minorities in the field of culture and education can rarely be found in the media, almost negligibly.

\subsection{Case 57325/00, DH and Others v The Czech Republic}

Claims of discrimination against national minorities also require a dose of caution, in order to prevent abuses with the intention of obtaining material benefits and additional rights guaranteed to national minorities. In practice, it is difficult to state with certainty whether certain acts constitute an act of discrimination against persons belonging to national minorities or whether they do not have such a character. This claim can be illustrated by the analysis of individual judgments of the European Court of Human Rights. Thus, in the case of D.H. and Others v. The Czech Republic, the applicants were 18 Czech nationals of Roma origin born between 1958 and 1991 who lived in the Ostrava district of the Czech Republic. Between 1996 and 1999, they were enrolled in special schools for children with learning difficulties, who were unable to follow the regular school program. According to the Czech law, the decision to enroll a child in a special school is made by the principal, and based on the results of tests for measuring the intellectual capacity of the child performed in a special Center, the consent of the child's legal representative is required. Twelve applicants appealed to the Constitutional Court, arguing that their enrollment in special schools was a general practice, creating segregation and racial discrimination through the parallel existence of two independent education systems, special schools for Roma and „normal“" schools for the majority of the population. This appeal was denied. Fourteen applicants requested the Ostrava Department of Education to reconsider the decision, arguing that the tests carried out were unreliable and that their parents had not been sufficiently informed of the consequences of giving consent. The Department of Education concluded that enrollment was done in accordance with the law. Thus, the applicants complained under Article 2 of Protocol No. 1 to the Convention, independently and in 
Pravni mehanizmi za zaštitu prava nacionalnih manjina u lokalnoj samoupravi u Republici Srbiji

conjunction with Article 14 of the Convention, that they had suffered discrimination in the exercise of their right to education on grounds of Roma origin. In its decision, the European Court noted that several organizations, including Council of Europe bodies, had expressed concern about the system under which Roma children living in the Czech Republic are placed in special schools and the difficulties they have in accessing regular schools. However, the Court emphasized that it was not for him to examine the social context, but to determine whether the reasons for the applicants' enrollment in the special schools were their ethnic or racial origin. The Court further found that the design and planning of educational programs in principle falls within the competence of the state in question, and that states cannot be prevented from establishing different types of schools for children with disabilities or in applying special educational programs in response to society's needs. In the applicants' case, the European Court of Human Rights noted that the rules for enrolling children in special schools did not relate to the ethnic origin of the pupils, but pursued the legitimate aim of adapting the education system to the needs and abilities or disabilities of children. The parents, as legal representatives, did not take any action, although they received clearly written decisions on the enrollment of their children in a special school. The applicants' representatives failed to refute the conclusions of the experts, who found that there were their learning difficulties. Later, some of the applicants' representatives were transferred to regular schools.

The court concluded that there was no violation of Art. 14. of the Convention in conjunction with Art. 2 of Protocol No. 1. However, Judge Cabral Baretto had a dissenting opinion in the present case, which he corroborated with the 1999 Report of the Czech Government which coincided with the time period when the said children were enrolled in schools. The report, cited by the judge, acknowledges that "Roma children with average or above-average intelligence are often placed in special schools based on the results of psychological tests, which are designed for the majority of the population and do not take into account Roma specifics." In his view, this constituted a discriminatory practice.

\section{Institutional mechanisms for the protection of the rights of national minorities in local self-government}

Councils for interethnic relations are the only institutional forms, which aim at achieving, protecting and promoting national equality, and function only in the area of local self-government. The legal basis for their establishment is contained in the Law on Local Self-Government, which provides for the mandatory establishment of councils for interethnic relations in nationally mixed units of local self-government. The Council is established as an independent working body, consisting of representatives of the Serbian people and national minorities, in accordance with the Law and the statute of local self-government. According to the composition of the council, we can say that it actually has the role of trying to establish and achieve good relations between members of the majority and minority people, on the territory of local self-government units, which contributes to the stability of interethnic relations. The Law on Local Self-Government, adopted in 2007, provided for the obligation to establish councils for interethnic relations in ethnically mixed 
municipalities, however, many local governments neglected their obligations. According to the latest Special Report of the Protector of Citizens on Councils for Interethnic Relations from 2017, it is stated that the legal condition for the formation of the Council is now met by 72 local self-government units, and that the Councils were established in 53 units, that is, that the legal obligation, established in 2007, was not fulfilled by all local self-governments (Zaštitnik građana, 2018).

The Protector of Citizens also noticed numerous irregularities and inconsistencies in the formation and work of the Council. It is worrying that the Councils in only six local self-government units gave an opinion or proposal on draft decisions, which they considered in 2015 and 2016, while in the previous two years in 40 local selfgovernments the Council did not give any opinion on draft decisions nor has it been required. It is noticeable that the councils for interethnic relations have not been given the appropriate role and significance. For making this even a possibility one might take into consideration the fact that there are insufficiently precise legal norms and unforeseen supervision, accompanied by inadequate sanctions for local selfgovernments, which, still, so many years after the existence of the legal obligation, do not form councils for interethnic relations, and then disobedience of the obligation to seek the opinion of the council, in specific cases, and on the occasion of decisionmaking of local governments (Zaštitnik građana, 2018).

Another body whose possibility of establishment in local self-governments is provided by the Law on Local Self-Government and which can contribute to the protection of human rights on the territory of a certain local community is the local ombudsman. The reason of existence of this body at the local level is that citizens can make a direct contact with a body that is authorized to independently control the respect of citizens' rights, determine violations committed by acts, actions or omissions of administrative bodies and public services, violations of regulations and general acts of the local selfgovernment unit. Members of the minority people can also turn to them, if they think that some right has been violated in this way.

Certainly, the most important institutional mechanism for exercising the rights of national minorities in the legal order of the Republic of Serbia are the national councils of national minorities. The National Council, among other things, gives an opinion in the procedure of adopting an act on the network of preschool institutions and primary schools in a local self-government unit in which the language of a national minority is in official use or in which educational work is performed in the language of a national minority. It distributes funds from the budget of the Republic autonomous province and local self-government units, which are awarded through a public competition to institutions and associations in the field of education. The National Council proposes to the competent authority to emphasize the names of local selfgovernment units, settlements and other geographical names in the language of the national minority; proposes the establishment of the language and script of the national minority as the official language and script of the local self-government unit; proposes a change in the names of streets, squares, city districts, hamlets, other parts of populated places, as well as institutions that have been determined to be of special importance for the national minority; gives an opinion in the procedure of determining the names of streets, squares. Although it is a body that has competencies in the field 
Pravni mehanizmi za zaštitu prava nacionalnih manjina u lokalnoj samoupravi u Republici $\underline{\text { Srbiji }}$

of culture, education, information and official use of language and script, elections for these bodies take all the features of the election procedure for political authorities, because they are based on the principles of freedom of choice, equality of suffrage, periodicity of elections and the principle of secret ballot (Nastić, 2017, p. 154).

\section{Conclusion}

With the Action Plan for Chapter 23 and the Action Plan for Exercising the Rights of National Minorities, the Republic of Serbia, on its European path, has committed itself to undertaking a number of legislative and institutional changes and measures aimed at promoting tolerance, understanding and cooperation, and fostering diversity. The currently achieved level of standards shows the seriousness in the realization of that goal, because it can be rightly said that Serbia has done a lot to protect the rights of members of national minorities. The legislative framework is increasingly in line with international standards, but work still needs to be done in order to find appropriate mechanisms for implementing certain legal solutions. Local governments, especially multiethnic ones, should have constant allocations from the budget, which would be used for various types of integration of members of national minorities. There is a noticeable lack of local government initiatives for various forms of essential integration of the Roma population, especially in the field of education and culture. Councils for interethnic relations, as the most important institutional mechanism for exercising the rights of national minorities at the local level, have not taken root, i.e. most local governments have not understood their purpose, that they should actually represent a bridge of stability in multiethnic municipalities. It is necessary to organize various types of education, local officials, on possible ways to protect members of national minorities, but also to educate members of national minorities about the opportunities and rights that belong to them, and how they can exercise them. The spirit of tolerance must be nurtured constantly, with the awareness that what is good for some doesn't have to necessarily mean that it is bad for others, more precisely that what contributes to some, members of the majority or minority people, does not harm others, but together, all individuals in one state, and especially in the area of local selfgovernment, where they are referred to each other every day, must fight to build a better society, and leave a legacy of equality to future generations. Only such a society of equality, tolerance, equal chances for employment, a society that preserves the cultural wealth of all nations, considering it a world cultural heritage, a society that understands, tolerates and accepts, is a society that can move forward.

\section{References}

Bašić, G., \& Đorđević, Lj. (2010). Ostvarivanje prava na službenu upotrebu jezika i pisama nacionalnih manjina u Republici Srbiji. Zaštitnik građana.

Belton, R., \& Avery, D. (1999). Employment Discrimination Law: Cases and Materials on Equality in the Workplace. West Group.

Dimitrijević, P., \& Vučetić, D. (2015). Ostvarivanje prava na službenu upotrebu jezika. Zbornik radova Pravnog fakulteta u Nišu, 70, 229-251. 
Kugelmann, D. (2007). The Protection of Minorities and Indigenous Peoples Respecting Cultural Diversity. Max Planck Yearbook of United Nations Law Online, 11(1), 233-263.

Marković, R. (2013). Ustavno parvo. Pravni fakultet Univerziteta u Beogradu, Centar za izdavaštvo i informisanje.

Minority news. (2019). Mesečni bilten o životu manjinskih zajednica u Srbiji, 52. https://www.minoritynews.rs/wp-content/uploads/2019/04/MN-52.pdf

Nastić, M. (2017). Pravni principi izbornog sistema, (2017). Pravni fakultetet u Nišu.

Nikčević, I., Krulj, J., Krulj-Mladenović, M., \& Jokanović, V. (2021). Inclusion: Movement for open and fair education. Bizinfo (Blace), 12(1), 43-52. https://doi.org/10.5937/bizinfo2101043N

Nowak, M. (2005). UN Covenant on Civil and Political Rights: CCPR Commentary, Kehl. Engel Publishers.

Pejić, I. (2009). Dejstvo ljudskih prava u pravnom poretku Srbije. U: N. Petrušić (ur). Pristup pravosuđu-instrumenti za implementaciju evropskih standarda $u$ pravni sistem Republike Srbije (55-68). Centar za publikacije Pravnog fakulteta u Nišu.

Pržić, I. (1933). Zaštita manjina. Doktorska disertacija, Pravni fakultet Univerziteta u Beogradu

United Nations Human Rights. (2012). Promoting and Protecting Minority Rights, A Guide for Advocates. United Nations Human Rights.

Zaštitnik građana. (2018). Poseban izveštaj zaštitnika građana o službenoj upotrebi albanskog jezika i pisma. Zaštitnik građana.

Ustav Republike Srbije. (2006). Službeni glasnik RS, br. 83/06,

Zakon o lokalnoj samoupravi. (2007). Službeni glasnik RS, 129/07; 83/214-dr zakon, 101/2016-dr.zakon i 47/2018.

Zakon o zaštiti prava i sloboda nacionalnih manjina. (2006). Službeni list SRJ, br. 11/2002, Službeni list SCG, br. 1/2003- Ustavnapovelja i Službeni glasnik RS, br. 72/2009- dr. zakon, 97/2013- odluka US i 47/2018.

Case 57325/00 DH and Others v The Czech Republic, no. 57325/00

Council of Europe. (1995). Framework Convention for the Protection of National Minorities. https://www.refworld.org/docid/3ae6b36210.html

Council of Europe. (2019). Advisory Committee on the Framework Convention for the Protection of National Minorities, Fourth Opinion on Serbia. https://rm.coe.int/4th-op-serbia-en/16809943b6

Received: 3 September, 2021; Accepted: 27 October, 2021.

Rad je primljen: 03.09.2021; Prihvaćen: 27.10.2021. 